\title{
Article
}

\author{
Doi 10.5943/sif/ 2/1/18
}

Copyright $\odot$ Mushroom Research Foundation

\section{Incidence of some agarics from the plains of Jammu, India}

\author{
Sharma R, Kumar S and Sharma YP
}

Department of Botany, University of Jammu, Jammu 180 006, Jammu and Kashmir, India

Sharma R, Kumar S and Sharma YP 2017 - Incidence of some agarics from the plains of Jammu, India. Studies in Fungi 2(1), 162-170, Doi 10.5943/sif/2/1/18

\begin{abstract}
The present communication sets out to examine the morpho-taxonomic studies of some agarics. A total of six species and two varieties viz., Agaricus californicus, $A$. placomyces, Chlorophyllum hortense, C. molybdites var. microsporus, C. nothorachodes, Leucoagaricus rhodocephalus, Leucocoprinus cepistipes and L. straminellus var. rubrum belonging to four genera have been collected, recorded, photographed and presented in the current paper. Survey of the literature showed that two species i.e. Agaricus californicus and Chlorophyllum hortense are new records for India, species namely Agaricus placomyces, Leucoagaricus rhodocephalus, Leucocoprinus cepistipes and C. nothorachodes are new for Jammu \& Kashmir whereas Chlorophyllum molybdites var. microsporus and Leucocoprinus straminellus var. rubrum are proposed as new varieties for science.
\end{abstract}

Key words - Agaricales - Jammu \& Kashmir - Morpho-taxonomy - New records

\section{Introduction}

Jammu (Jammu \& Kashmir, India) is situated to the south of the great Himalayan range and North of the plains of Punjab. Located at $32.73^{\circ} \mathrm{N}$ and $74.87^{\circ} \mathrm{E}$ and covering approximately 3,250 sq. $\mathrm{km}$ area, the land serves as a host for many wild macrofungi mostly represented by the members of agarics, a very well-known group of mushrooms having global representation. The group includes small to very large terrestrial mushrooms with a central stalk that separates easily from the cap. Agarics are unquestionably, the most significant group of gilled mushrooms from both an economic and gastronomic standpoint as it includes the familiar cultivated as well as a large number of other detectable collectibles. Cap varies from smooth to scaly, typically neither brightly coloured nor viscid. Flesh usually white (Arora 1986). It is widely distributed, actually a prominent group of terrestrial fungi that shows a variety of ecological roles as saprophytes, mutualists and parasites (Moncalvo et al. 2000).

\section{Materials \& Methods}

Frequent visits to three different collection sites (Bajalta, R.S Pura and University Campus) in district Jammu were made during the year 2015 . The specimens were carefully uprooted by gently lifting them up in order to avoid damage to the base. Various primary morphological details like size, colour, texture, shape, flesh, gills, stalk and annulus of the fruiting bodies were recorded on the field key designed for the purpose (Atri et al. 2003). The pertinent details about the occurrence, identification and collection of the species were also recorded from the localities. For microscopic observations, dried samples were first revived in $5 \% \mathrm{KOH}$ and then studied in Congo red (1g 
Congo red $+99 \mathrm{ml}$ distilled water) and Melzer's reagent (chloral hydrate $22 \mathrm{~g}+$ potassium iodide $1.5 \mathrm{~g}+$ iodine $0.5 \mathrm{~g}+$ distilled water $20 \mathrm{ml}$ ). Faces of fungi number of the documented species are also provided (Jayasiri et al. 2015).

\section{Taxonomy}

Agaricus californicus Peck, Bull. Torrey bot. Club 22: 203 (1895)

Figs $1 \mathrm{a}, \mathrm{b} \& 2 \mathrm{~A}$

Facesoffungi Number: FoF03443

Synonymy: Fungus californicus (Peck) Kuntze, Revis. gen. pl. (Leipzig) 3(2): 479 (1898)

Pileus $9.6 \mathrm{~cm}$ wide, initially convex, then expanding becoming broadly convex to plane, yellowish cream, scales present, flesh thick. Gills free, sub-distant to crowded, dark brown. Stipe $7.5 \mathrm{~cm}$ long and $1.2 \mathrm{~cm}$ wide, equal, central, bulbous from the base. Annulus present, thick, membranous, persistent with patches. Edibility not edible in the study area.

Basidia 19.2-22.4 × 4.8-6.4 $\mu \mathrm{m}$, clavate, hyaline. Sterigmata 1.6-2.4 $\mu \mathrm{m}$ long. Basidiospores 4.8-7.2 $\times$ 4.0-5.6 $\mu \mathrm{m}, \mathrm{a}_{\mathrm{v}} \mathrm{L}=6.0, \mathrm{a}_{\mathrm{v}} \mathrm{W}=4.8, \mathrm{Q}=1.2-1.28$, hyaline, thick walled, elliptical, apiculate, dark olive green to pale green (same colour in Melzer's reagent), inamyloid. Spore print chocolate brown. Pileus and stipe context hyphae 3.2-4.8 $\mu \mathrm{m}$ and 4.0-5.6 $\mu \mathrm{m}$ wide respectively, hyaline, thin walled, septate, unbranched. Annulus hyphae 6.4-8.8 $\mu \mathrm{m}$ wide, hyaline, septate, branched.

Collection examined - India, Jammu \& Kashmir, Jammu, Bajalta, humicolous, 17 Jul 2015, Roshi Sharma \& Y.P. Sharma, HBJU 405.

Distribution - Earlier reported from North America.

Remarks - The current species constitutes a new record for India. The macroscopic and microscopic details of the above described specimen are in conformity with that given by Arora (1986). Typically found solitary to scattered, the species has many morphological similarities with Agaricus xanthodermus, A. campestris and A. bisporus but can be set apart by the presence of persistent membranous annulus, whitish gills when young and slight phenolic odour.

Agaricus placomyces Peck, Ann. Rep. N.Y. St. Mus. nat. Hist. 29: 40 (1878) [1876]

Facesoffungi Number: FoF03442

Figs $1 \mathrm{c}, \mathrm{d} \& 2 \mathrm{~B}$

Synonymy: Agaricus placomyces var. microsporus A.H. Sm., Pap. Mich. Acad. Sci. 25: 125 (1940)

Agaricus placomyces var. flavescens Thiers, Mycologia 51(4): 538 (1960)

Pileus $5.0 \mathrm{~cm}$ wide, expanded convex with a low broad umbo, white, flesh having greyish brown scales all over the surface, cap yellow with $\mathrm{KOH}$, radially splitting on maturity. Gills pinkish to light brownish, unequal, free, crowded. Stipe $5.2 \mathrm{~cm}$ long and $0.5 \mathrm{~cm}$ wide, white, nearly equal ending with a slight bulbous base. Annulus present, white membranous band like with cottony patches. Edibility unknown.

Basidia 17.6-27.2 $\times 6.4-8.0 \mu \mathrm{m}$, clavate, thin walled, hyaline. Sterigmata 1.6 to $2.4 \mu \mathrm{m}$ long. Basidiospores 4.0-5.6 $\times$ 2.4-3.2 $\mu \mathrm{m}, \mathrm{a}_{\mathrm{v}} \mathrm{L}=4.8, \mathrm{a}_{\mathrm{v}} \mathrm{W}=2.8, \mathrm{Q}=1.66-1.75$, elliptic, apiculate, monoguttulated. Spore print brown. Pileus and stipe context hyphae 6.0 to 8.0 and 4.0 to $24.0 \mu \mathrm{m}$ respectively, hyaline, septate. Annulus hyphae 4.0 to $14.0 \mu \mathrm{m}$, hyaline, branched, septate.

Collection Examined - India, Jammu \& Kashmir, Jammu, R.S. Pura, coprophilous, single, 6 Jul 2015, Roshi Sharma \& Y.P. Sharma, HBJU 406.

Distribution - This species has been earlier reported from Central India, Maharashtra.

Remarks - This species have been reported from Central India by Karwa \& Rai 2010. The present collection is found to be a new record for Jammu \& Kashmir. The species closely resembles with the description given by Bessette et al. (1997) except for habitat difference as the current specimen was found to be coprophilous whereas Bessette et al. (1997) reported it to be lignicolous.

Chlorophyllum hortense (Murrill) Vellinga, Mycotaxon 83: 416 (2002)

Figs $1 \mathrm{e}, \mathrm{f} \& 2 \mathrm{C}$

Facesoffungi Number: FoF03444 

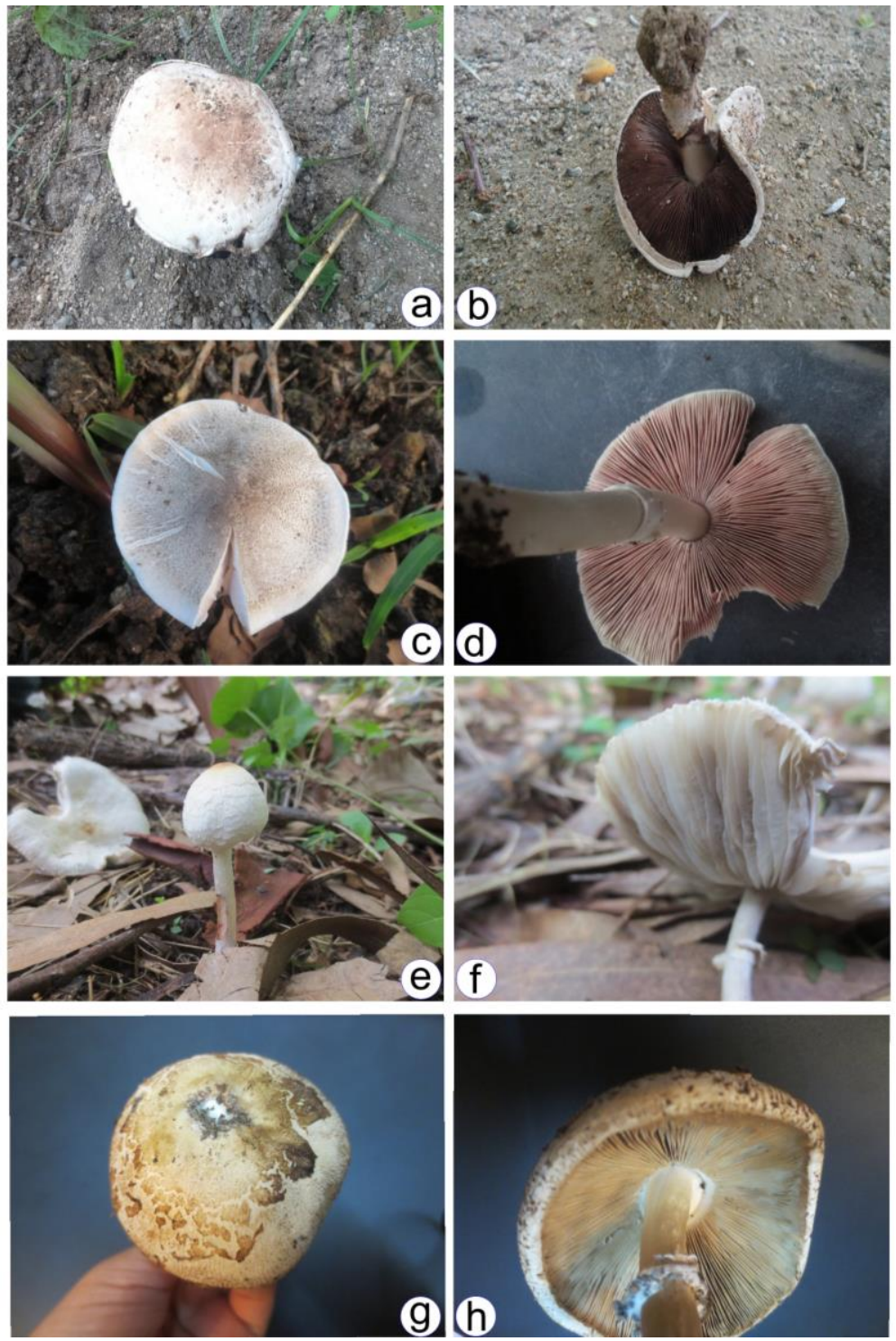

Fig. 1 - a Pileus surface view of Agaricus californicus. b Ventral surface view of A. californicus showing hymenium and stipe. c Basidiocarps of Agaricus placomyces in natural habitat. d Undersurface view of A. placomyces showing gills. e Young basidiocarp of Chlorophyllum hortense in natural habitat. f Mature basidiocarp of $C$. hortense showing lamellae and annulus. $\mathrm{g}$ Basidiocarp of Chlorophyllum molybdites var. microsporus. h Undersurface view of $C$. molybdites var. microsporus showing free gills.

Synonymy: Lepiota hortensis Murrill, N. Amer. Fl. (New York) 10(1): 59 (1917)

Leucoagaricus hortensis (Murrill) Pegler, Kew Bull., Addit. Ser. 9: 414 (1983)

Pileus $6.5 \mathrm{~cm}$ wide, oval or nearly round when young, becoming convex to plane on maturity, centre tinged yellow brown, yellowish brown squamules on white background, red on bruising, striated margins. Gills white to greyish, broad, unequal and free. Stipe 4.5 to $6.0 \mathrm{~cm}$ long and up to $0.7 \mathrm{~cm}$ wide, white from upper portion and brown from the base, equal, central. Annulus present, white, movable in age, persistent. Edibility inedible in the study area, considered edible by some, suspected by others.

Basidia 17.6-24.0 × 7.2-9.6 $\mu \mathrm{m}$, clavate, hyaline. Basidiospores 6.4-8.0 $\times$ 4.8-5.6 $\mu \mathrm{m}$, $\mathrm{a}_{\mathrm{v}} \mathrm{L}=7.2, \mathrm{a}_{\mathrm{v}} \mathrm{W}=5.2, \mathrm{Q}=1.3-1.4$, ellipsoid, apiculate, germ pore absent, monoguttulated, olive green to light blue, dextrinoid, smooth. Pileus and stipe context hyphae 4.0 to $12.0 \mu \mathrm{m}$ and 8.0 to $18.0 \mu \mathrm{m}$ wide respectively, hyaline, septate.

Collection examined - India, Jammu \& Kashmir, Jammu, University Campus, from litter, 
humicolous, 4 Aug 2015, Roshi Sharma \& Y.P. Sharma, HBJU 408.

Distribution - Reported from China and Brazil.

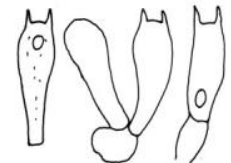

a
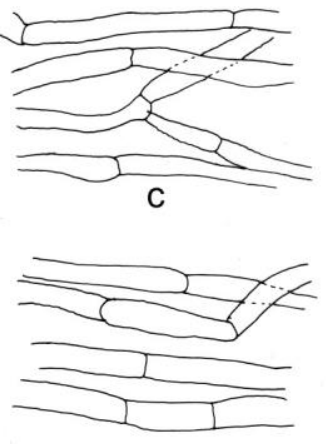

d

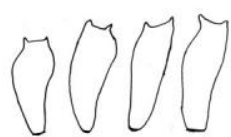

a

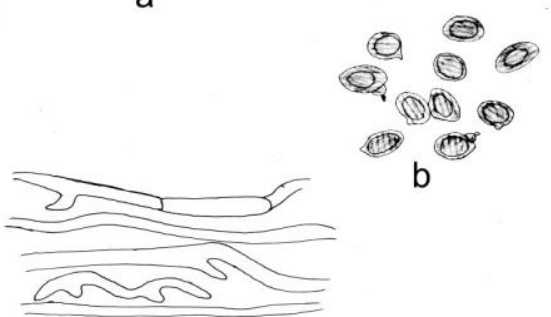

C
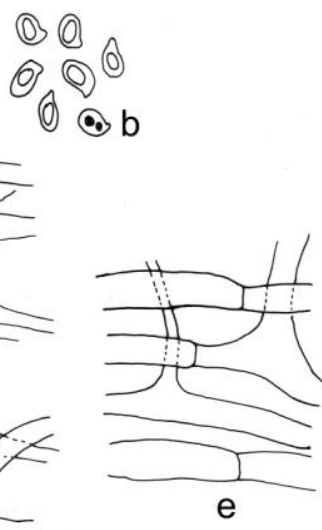

A B

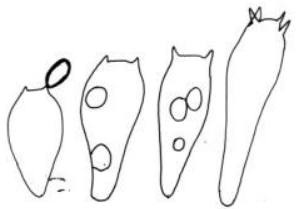

a

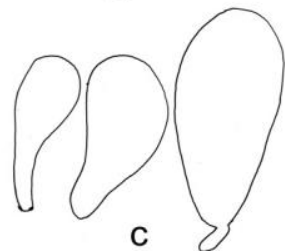

C

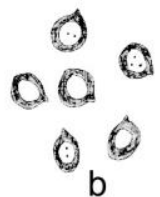

$\mathrm{b}$

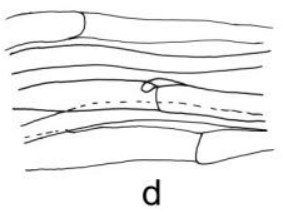

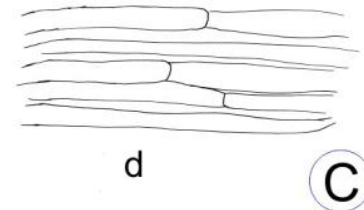
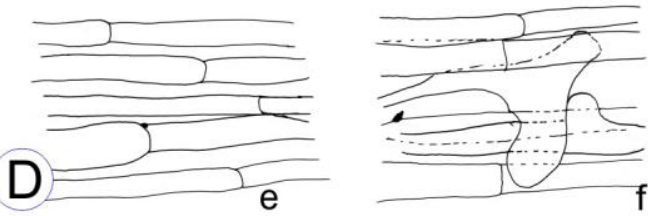

Fig. 2 - A Agaricus californicus a) basidia b) basidiospores c) pileus context hyphae d) stipe context hyphae e) annulus hyphae. Scale bars: a-e $=10 \mu \mathrm{m}$.

B Agaricus placomyces a) basidia b) basidiospores c) pileus context hyphae d) stipe context hyphae e) annulus hyphae. Scale bars: $\mathrm{a}-\mathrm{e}=10 \mu \mathrm{m}$.

C Chlorophyllum hortense a) basidia b) basidiospores c) pileus context hyphae d) stipe context hyphae. Scale bars: $\mathrm{a}-\mathrm{d}=10 \mu \mathrm{m}$.

D Chlorophyllum molybdites var. microsporus a) basidia b) basidiospores c) pileus context hyphae d) stipe context hyphae e) annulus hyphae. Scale bars: $\mathrm{a}-\mathrm{f}=15 \mu \mathrm{m}$.

Remarks - A new record for India. This species has been reported by Ge \& Yang 2006, Nascimento \& Alves 2014. Most of the features of the above described specimen are in line with the description given by Vellinga (2003) except for spore size which is smaller in our case. The 
species can be easily identified by its medium sized basidiocarp, white squamules on the surface of pileus along with yellowish apex and a strong reddening of stipe on bruising.

Chlorophyllum molybdites var. microsporus Sharma R \& Sharma YP var. nov. Figs 1g,h \& 2D Facesoffungi Number: FoF03445

Etymology - named for the small size of its basidiospores.

Typification/holotype - India, Jammu \& Kashmir, Jammu, Bajalta, humicolous, gregarious, 17 Jul 2015, Roshi Sharma \& Y.P. Sharma, HBJU 409.

Diagnosis - Differing from $C$. molybdites in having small and cyanophilous basidiospores.

Pileus $7 \mathrm{~cm}$ wide, oval to round, then becoming broadly cone to convex, surface white, dry soon breaking into brown scales that are more towards center. Gills greyish-white, unequal and free from stipe. Stipe 12.0 to $13.5 \mathrm{~cm}$ long and 0.6 to $1.3 \mathrm{~cm}$ wide, solid, sub-cylindrical, white, equal. Annulus present, greyish white, double edged. Edibility considered being poisonous.

Basidia 18.4-33.6 × 9.6-11.2 $\mu \mathrm{m}$, clavate, hyaline. Basidiospores 3.2-9.6 × 3.2-6.4 $\mu \mathrm{m}$, $\mathrm{a}_{\mathrm{v}} \mathrm{l}=6.4, \mathrm{a}_{\mathrm{v}} \mathrm{W}=4.8, \mathrm{Q}=1.0-1.5$, elliptic, bluish green, apiculate, smooth, dextrinoid, apical pore present, thick walled, monoguttulated. Cystidia 27.2-36.8 $\times 11.2-17.6 \mu \mathrm{m}$, broadly clavate, hyaline. Pileus context hyphae 3.2 to $20.8 \mu \mathrm{m}$, hyaline, septate and clamped. Stipe and annulus hyphae 2.4 to $16.0 \mu \mathrm{m}$ and 4.8 to $11.2 \mu \mathrm{m}$ wide respectively, hyaline, septate.

Remarks - The examined collection resembles Chlorophyllum molybdites in most of characters but differed prominently in terms of its small size of basidiospores $(3.2-9.6 \times 3.2-6.4$ $\mu \mathrm{m})$ and the fruiting body $(7 \mathrm{~cm})$ as well as cyanophilous nature of spores. With the presence of these differences, the examined taxon has been proposed as a new variety.

Chlorophyllum nothorachodes Vellinga \& Lepp, in Vellinga, Aust. Syst. Bot. 16(3): 363 (2003)

Facesoffungi Number: FoF03446

Figs $3 \mathrm{a} \& 4 \mathrm{~A}$

Pileus 6.0-14.0 cm wide, oval when young, then becoming convex, creamish with dark brown raised squamules present in concentric manner that are more concentrated towards centre, flesh thick, margins striated. Gills crowded, free, white then turned greyish, broad. Stipe upto $8 \mathrm{~cm}$ long and $2.0 \mathrm{~cm}$ broad white, becoming brown on bruising, broad from the base. Annulus present, double ridged, detachable, white. Edibility non-edible.

Basidia 27.2-32.0 $\times$ 9.6-11.2 $\mu \mathrm{m}$, hyaline, clavate. Sterigmata 4.0-6.4 $\mu \mathrm{m}$ long. Basidiospores 8.0-10.4 × 5.6-7.2 $\mu \mathrm{m}$, ellipsoid, olive green, double walled, monoguttulated. Pileus context hyphae $8.0 \mu \mathrm{m}$ wide, inflated up to $28.0 \mu \mathrm{m}$, hyaline, branched, septate. Stipe hyphae 4.0$28.0 \mu \mathrm{m}$, hyaline, branched, septate. Annulus hyphae 4.0-12.0 $\mu \mathrm{m}$ wide, dimitic.

Collection examined - India, Jammu \& Kashmir, Jammu, Bajalta, gregarious, humicolous, 15 Sept 2015, Roshi Sharma \& Y.P. Sharma, HBJU 410.

Distribution - Known from U.S.A and India.

Remarks - Current species is found to be a new addition to the existing mycobiota of Jammu \& Kashmir State. The species was first described by Vellinga in the year 2003 having large sized caps covered with brown coloured squamules, closely crowded gills and thick walled basidiospores. Recently, this species has been reported from Southern India by Priyamvada et al. (2017).

Leucoagaricus rhodocephalus (Berk.) Pegler, Kew Bull. 30(3): 432 (1975)

Figs $3 b, c \& 4 B$

Facesoffungi Number: FoF03447

Synonymy: Lepiota rhodocephala (Berk.) Sacc., Syll. fung. (Abellini) 5: 59 (1887)

Mastocephalus rhodocephalus (Berk.) Kuntze, Revis. gen. pl. (Leipzig) 2: 860 (1891)

Pileus $6.4 \mathrm{~cm}$ wide, convex, expanded with broad obtuse umbo, grenadine (II b.7. R-O.), fading towards margins, cuticle easily peeling, flesh white. Gills pure white, unequal, free, subdistant with smooth edges. Stipe $5.5 \mathrm{~cm}$ long and $1.8 \mathrm{~cm}$ wide white, cylindrical, equal with slight bulbous base. Annulus present, membranous, central. Edibility not known in the study area. 
Basidia $12.8-20.0 \times 6.4-8.8 \mu \mathrm{m}$, broadly clavate, hyaline. Sterigmata 1.6 to $4.8 \mu \mathrm{m}$ long. Basidiospores 2.4-8.8 $\times 1.6-4.0 \mu \mathrm{m}, \mathrm{a}_{\mathrm{v}} \mathrm{L}=5.6, \mathrm{a}_{\mathrm{v}} \mathrm{W}=2.8, \mathrm{Q}=1.5-2.2$, ellipsoid, hyaline, dextrinoid, mono to biguttulated, apical pore absent. Cheilocystidia 19.2-22.4 $\times 8.0-11.2 \mu \mathrm{m}$, hyaline, thin walled, cylindrical to clavate. Pileus and stipe context hyphae 4.0 to 24.0 and 4.0 to $28.0 \mu \mathrm{m}$ respectively, hyaline, septate.

Collection Examined - India, Jammu \& Kashmir, Jammu, University Campus, humicolous, single, 13 Jul 2015, under Delonix regia, Roshi Sharma \& Y.P. Sharma, HBJU 418.

Remarks - The survey of literature reveals that the examined specimen has not been earlier reported from Jammu \& Kashmir State. Hence, the present described species constitutes as a new record for the State.
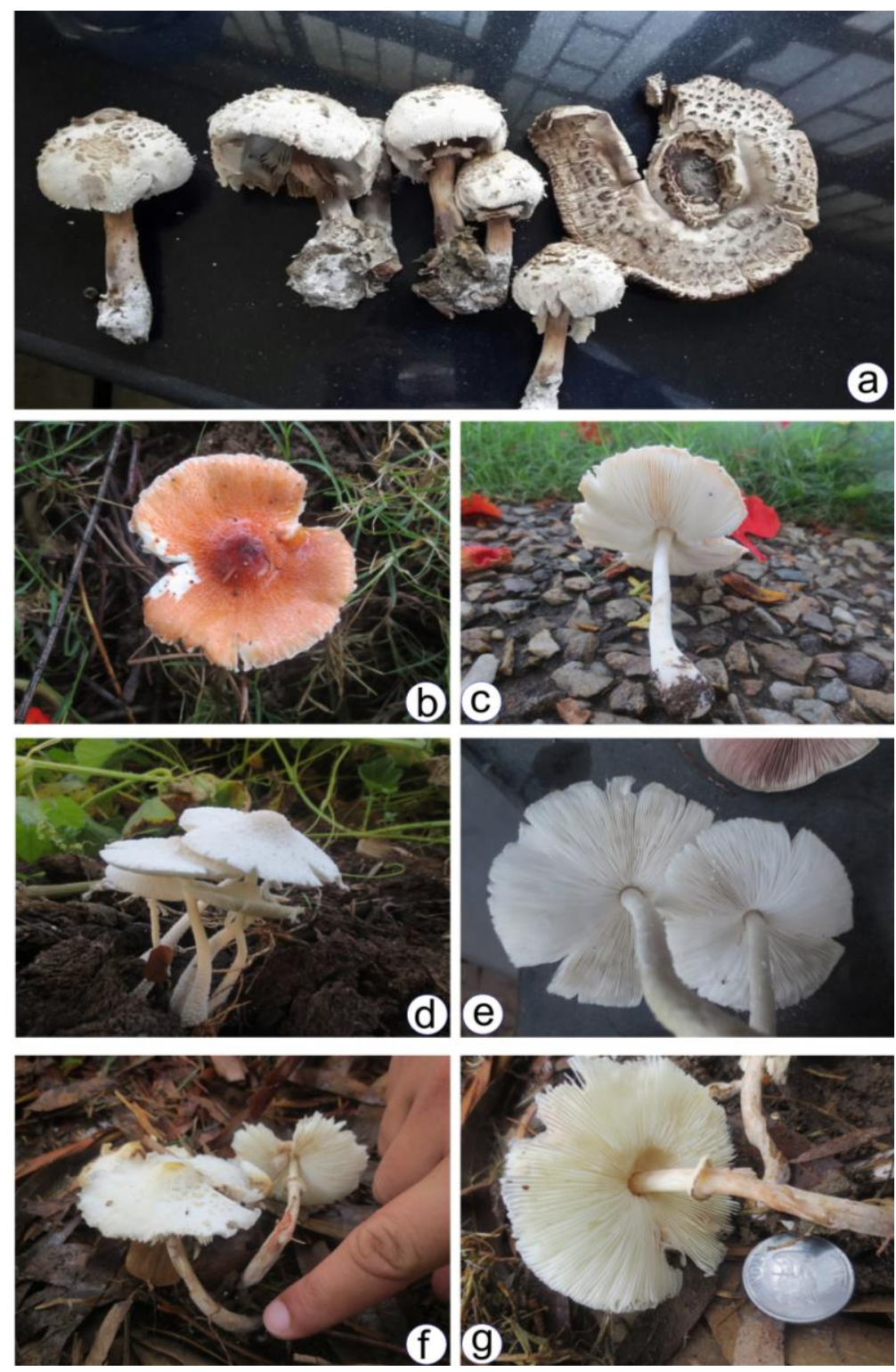

Fig. 3 - a Young and mature basidiocarps of Chlorophyllum nothorachodes. b Pileus surface view of Leucoagaricus rhodocephalus in natural habitat. c Undersurface view of Leucoagaricus rhodocephalus showing pure white gills and bulbous base of stipe. $\mathrm{d}$ Basidiocarps of Leucocoprinus cepistipes blooming on cattle dung. e Undersurface view of Leucocoprinus cepistipes showing powdery dust all over the surface. f Basidiocarps of Leucocoprinus straminellus var. rubrum growing on leaf litter. g Lower surface view of the Basidiocarp of Leucocoprinus straminellus var. rubrum. 

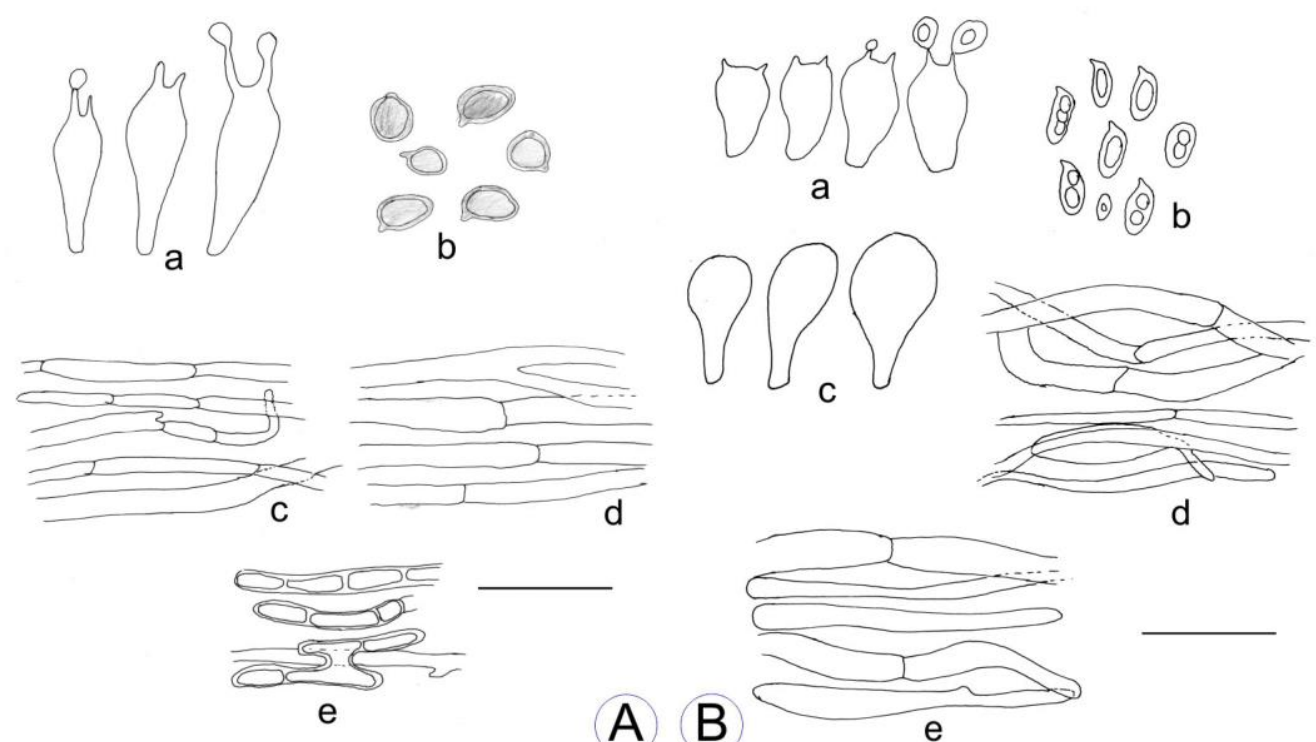

A B
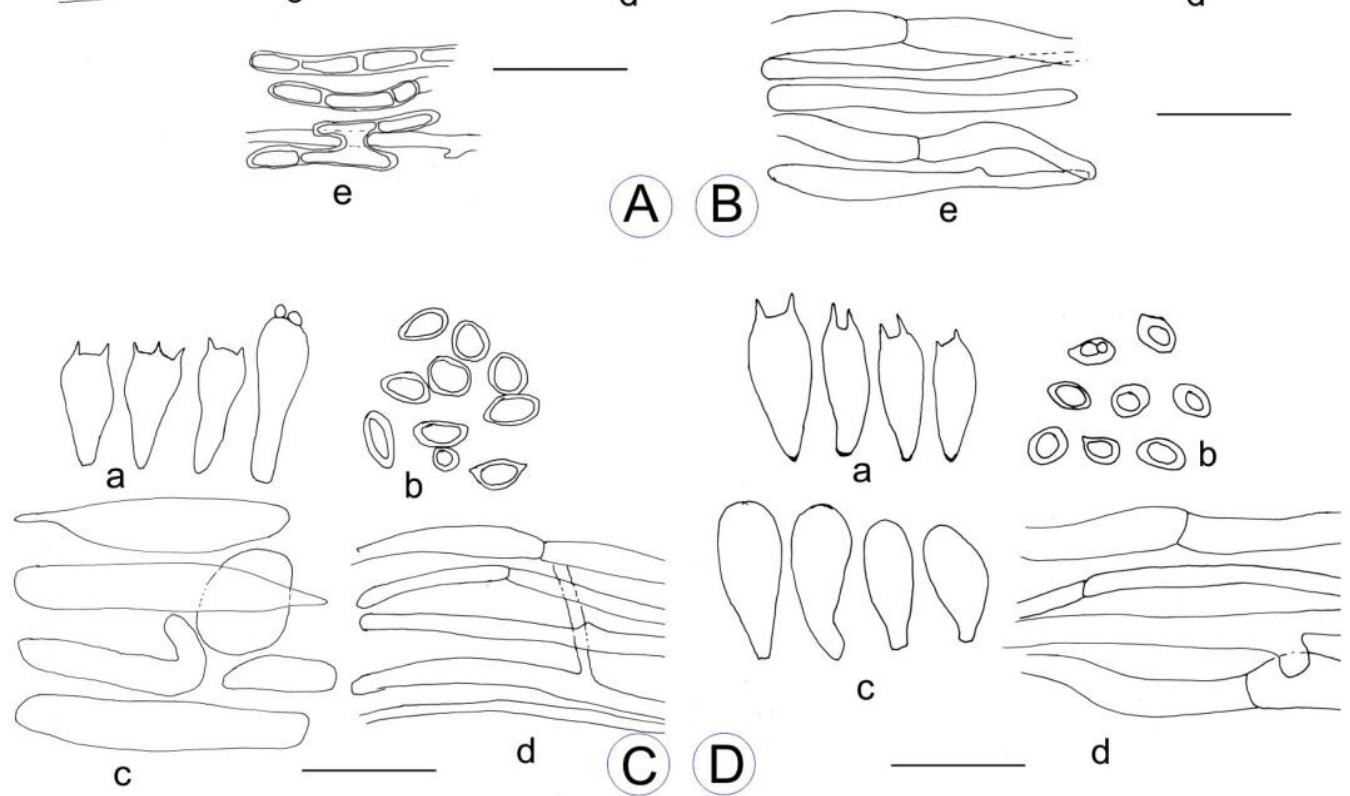

Fig.4 - A Chlorophyllum nothorachodes a) basidia b) basidiospores c) pileus context hyphae d) stipe context hyphae e) annulus hyphae. Scale bars: a-e $=15 \mu \mathrm{m}$.

B Leucoagaricus rhodocephalus a) basidia with attached basidiospores b) basidiospores c) cheilocystidia d) pileus context hyphae e) stipe context hyphae. Scale bars: a-e $=15 \mu \mathrm{m}$. C Leucocoprinus cepistipes a) basidia b) basidiospores c) pileipellis elements d) stipe context hyphae. Scale bars: a-d $=15 \mu \mathrm{m}$.

D Leucocoprinus straminellus var. rubrum a) basidia b) basidiospores c) pileocystidia d) stipe context hyphae. Scale bars: a-d $=15 \mu \mathrm{m}$.

Leucocoprinus cepistipes (Sowerby) Pat. [as 'cepaestipes'], J. Bot., Paris 3: 336 (1889)

Facesoffungi Number: FoF03448

Figs $3 d, e$ \& $4 \mathrm{C}$

Synonymy: Leucocoprinus cepistipes f. macrosporus Migl., Boll. Assoc. Micol. Ecol. Romana 3(nos 6-7): 18 (1986)

Leucocoprinus cepistipes var. pseudofarinosus Raithelh. [as'caepestipes'], Nueva Flora Micológica Argentina (Stuttgart): 524 (2004)

Pileus 2.5-5.3 cm broad, expanded, convex, white, granulated, powdery, subumbonate, margins serrated or rimose. Gills purely white, unequal, free and white powder dusted all over the 
surface. Stipe 4 to $11 \mathrm{~cm}$ long, upto $0.6 \mathrm{~cm}$ broad white, broad at the base. Edibility not eaten in the study area.

Basidiospores 6.4-9.6 × 4.8-5.6 $\mu \mathrm{m}, \mathrm{a}_{\mathrm{v}} \mathrm{L}=8.0, \mathrm{a}_{\mathrm{v}} \mathrm{W}=5.2, \mathrm{Q}=1.3-1.92$, thick walled, ellipsoid, smooth, apiculated, hyaline. Basidia $16.0-32.0 \times 8-11.2 \mu \mathrm{m}$ clavate, hyaline. Sterigmata $2-4$ in number, 1.6 to $3.2 \mu \mathrm{m}$ long. Pileipellis elements 4.8 to $16 \mu \mathrm{m}$ wide hyaline, smooth walled, inflated. Stipe hyphae hyaline, branched, septate, clamp connections not found, 1.6 to $14.4 \mu \mathrm{m}$ wide.

Distribution - Earlier reported from Argentina and India.

Collection Examined - India, Jammu \& Kashmir, Jammu, R.S Pura, coprophilous, caespitose, 6 Jul 2015, Roshi Sharma \& Y.P. Sharma, HBJU 420.

Remarks - The current specimen was reported from Punjab, India (Kaur et al. 2015) but not yet known for Jammu \& Kashmir, thus constituting a new addition for the State.

Leucocoprinus straminellus var. rubrum Sharma R \& Sharma YP var. nov. $\quad$ Figs 3f,g \& 4D

Facesoffungi Number: FoF03449

Etymology - named due to reddening of stipe on bruising

Typification/holotype - India, Jammu \& Kashmir, Jammu, University Campus, gregarious, humicolous, on leaf litter, 14 Aug 2015, Roshi Sharma and Y.P. Sharma, HBJU 421.

Diagnosis - Differing from L. straminellus in turning red on bruising and easily peeling off of cuticle along with less prominent striations.

Pileus 3.5-4.0 cm wide, white, conico-convex, broad umbo of yellowish brown colour, scales appressed covering the entire surface. Gills white, free, equal, sub-distant. Stipe 9.0 to $10.0 \mathrm{~cm}$ long bearing ring like median annulus, creamy white, central, slightly broad at the base, coloured red on bruising. Edibility not eaten in the study area.

Basidia 16.0-30.4 × 8.0-9.6 $\mu \mathrm{m}$, hyaline, thin walled and clavate. Sterigmata 3.2 to $4.8 \mu \mathrm{m}$ long. Basidiospores 4.8-8.0 3 3.2-5.6 $\mu \mathrm{m}, \mathrm{a}_{\mathrm{v}} \mathrm{L}=6.4, \mathrm{a}_{\mathrm{v}} \mathrm{W}=4.4, \mathrm{Q}=1.5-1.43$, hyaline, thick walled, dextrinoid, germ pore absent, apiculated, monoguttulated, smooth, ellipsoid. Pileocystidia 17.6$36.8 \times 8.0-11.2 \mu \mathrm{m}$, hyaline. Stipe hyphae 4.0-17.6 $\mu \mathrm{m}$, hyaline, branched, septate.

Remarks - The present species resembles both macro- and microscopically (yellowish brown colour, median annulus and ellipsoid basidiospores without germ pore) with Leucocoprinus straminellus but difference lies with respect to certain points like the flesh of current species turns red on bruising, easily peeling off of cuticle and less prominent striations on pileus. On the basis of above sharp differences, the present taxon is proposed as a new variety for science.

\section{Acknowledgements}

Authors would like to express special thanks of gratitude to the Head, Department of Botany (UGC-SAP DRS), University of Jammu, Jammu for providing laboratory facilities.

\section{References}

Arora D. 1986 - Mushroom demystified. A comprehensive guide to fleshy fungi. Ten Speed Press, Berkeley, California, 936 p.

Atri NS, Kaur A, Kaur H. 2003 - Wild mushrooms-collection and identification. Mushroom Research 14, 56-59.

Bessette AE, Bessette AR, Fischer WD. 1997 - Mushrooms of Northeastern North America. Syracuse University Press, Hong Kong, 582 p.

Ge ZW, Yang ZL. 2006 - The genus Chlorophyllum (Basidiomycetes) in China. Mycotaxon 96, $181-191$.

Jayasiri SC, Ariyawansa HA, Liu JK, Jones EBG, Hyde KD. 2015 - The faces of fungi database: Fungal names linked with morphology, phylogeny and human impacts. Fungal Diversity 74, $2-18$. 
Karwa A, Rai MK. 2010 - Hitherto unreported Agaricus species of Central India. Nusantara Bioscience 2, 141-145.

Kaur A, Atri NS, Kaur M. 2015 - Ecology, distribution perspective, economic utility and conservation of coprophilous agarics (Agaricales, Basidiomycota) occurring in Punjab, India. Current Research in Environmental \& Applied Mycology 5, 213-247.

Moncalvo JM, Lutzoni FM, Rehner SA, Johnson J, Vilgalys R. 2000 - Phylogenetic relationships of agaric fungi based on nuclear large subunit ribosomal DNA sequences. Systematic Biology 49, 278-305.

Nascimento CC, Alves MH. 2014 - New records of Agaricaceae (Basidiomycota, Agaricales) from Araripe National Forest, Ceara State, Brazil. Mycosphere 5, 319-332.

Priyamvada H, Akila M, Singh RK, Ravikrishna R et al. 2017 - Terrestrial macrofungal diversity from the tropical dry evergreen biome of Southern India and its potential role in aerobiology. Plos One 12,1-21.

Vellinga EC. 2003 - Phylogeny of Lepiota (Agaricaceae) - evidence from nrITS and nrLSU sequences. Mycological Progress 2, 305-322. 